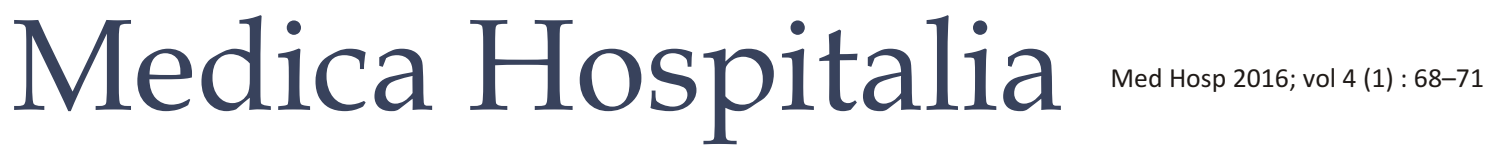

Clinical Practice

\section{Diagnosis dan Tatalaksana Hiperplasia Adrenal Kongenital}

\author{
Agustini Utari \\ Divisi Endokrinologi Anak- Departemen Ilmu Kesehatan Anak, \\ Fakultas Kedokteran Universitas Diponegoro / RSUP Dr. Kariadi, Semarang
}

\begin{abstract}
Abstrak
Hiperplasia Adrenal Kongenital (HAK) merupakan suatu kelainan autosomal resesif yang menyebabkan terjadinya gangguan pembentukan kortisol akibat defek enzimatik pada steroidogenesis. Tipe HAK terbanyak adalah defisiensi 21hidroksilase. Manifestasi klinik HAK akibat defisiensi 21hidroksilase secara umum bisa dbagi menjadi tipe klasik dan non klasik. Tipe klasik dibedakan menjadi dua kelompok yakni tipe salt wasting (kekurangan garam) dan simple virilizing. Diagnosis ditegakkan berdasarkan peningkatan kadar serum 17 hidroksiprogresteron (17OHP). Pengobatan utama adalah dengan memberikan glukokortikoid dengan atau tanpa mineralokortikoid.
\end{abstract}

Kata kunci : Hiperplasia Adrenal Kongenital, defisiensi 21hidroksilase, kekurangan garam, simple virilizing

\section{PENDAHULUAN}

Hiperplasia Adrenal Kongenital (HAK) atau Congenital Adrenal Hyperplasia (CAH) merupakan suatu kelainan autosomal resesif dimana terjadi gangguan pembentukan kortisol akibat hambatan dari salah satu tahap enzimatik yang dibutuhkan untuk biosintesis kortisol dan aldosteron. ${ }^{1,2}$ Tipe HAK terbanyak adalah defisiensi 21-hydroxylase yang merupakan 95\% kasus dan merupakan penyebab terbanyak kelainan autosomal resesif. ${ }^{3,4}$ Tipe HAK lainnya adalah 11k-hydroxylase deficiency, 17a-hydroxylase/17,20 lyase deficiency, $3 \beta$ steroid dehydrogenase deficiency, P450 and Oxidoreductase (POR) deficiency. ${ }^{5}$

Prevalensi HAK tipe klasik diperkirakan 1 : 10.000-20.000 kelahiran, meskipun didapatkan peningkatan prevalensi pada beberapa etnik tertentu. . $^{2,3}$

\section{Diagnosis and treatment of Congenital Adrenal Hyperplasia}

\begin{abstract}
Congenital adrenal hyperplasia (CAH) is an autosomal recessive disorders due to enzymatic defects in the steroid metabolic pathway which is lead to impairment in the adrenal cortisol biosynthesis. The most common form of CAH is 21-hydroxilase deficiency. The clinical manifestation of 21-hydroxilase deficiency can be divided into classic and non classic form. The classic form of $\mathrm{CAH}$ is categorized into two group, salt wasting and simple virilizing type. The diagnosis is confirmed by increasing level of 17 hydroxiprogresterone (17OHP) serum. The glucocorticoid with or without mineralocorticoid is the main treatment of $\mathrm{CAH}$.
\end{abstract}

Keywords : Congenital Adrenal Hyperplasia, 21-hydroxylase deficiency, salt wasting, simple virilizing
Frekuensi pembawa/karier defisiensi 21-hydroxylase tipe klasik atau berat diperkirakan 1 diantara 60 orang. Frekuensi karier defisiensi 21- hydroxylase tipe nonklasik atau bentuk ringan berkisar 1-5 diantara 50 orang, tergantung etniknya. ${ }^{4}$

Derajat berat kelainan ini bervariasi, tergantung pada aktivitas enzim residual. Secara umum HAK dibagi menjadi tipe klasik dan non klasik. Tipe klasik terdiri dari tipe kekurangan garam (salt wasting) dan tipe tanpa kekurangan garam (non-salt wasting). Pada HAK klasik tipe kekurangan garam, aktivitas enzim residual kurang dari 1\%.7, Akibat kekurangan kortisol dan atau aldosteron maka individu dengan HAK tipe klasik harus mendapatkan pengobatan seumur hidup., 3,9,10

Memahami tentang patogenesis, gambaran klinis dan terapi pada HAK diharapkan akan membantu meningkatkan kewaspadaan terhadap HAK, 
mengurangi mortalitas dan meningkatkan kualitas hidup penderita HAK. Pada tulisan ini akan memfokuskan pada diagnosis dan terapi HAK yang disebabkan oleh 21-hydroxylase deficiency.

\section{Patogenesis}

Kortek adrenal mempunyai 3 zona yakni zona gromerulosa, zona fasikulata dan zona retikularis yang menghasilkan berturut-turut mineralokortikoid, glukokortikoid dan steroid seks. Kelenjar adrenal menghasilkan glukokortikoid dan steroid seks sebagai respon terhadap adrenocorticotropic hormone (ACTH) dan diatur oleh $\mathrm{ACTH}$, corticotropin releasing hormone $(\mathrm{CRH})$ dan arginin-vasopressin. ACTH menstimulasi androgen sekaligus kortisol. Kortisol akan memberikan umpan balik negatif baik ke hipofise maupun hipotalamus dan menekan ACTH, CRH dan arginin-vasopresin.7

Pada HAK terjadi defisiensi enzim yang berperan dalam proses steroidogenesis yakni proses pembentukan hormon steroid dari kolesterol. CYP21 mengubah 17hydroxyprogesterone (17OHP) menjadi 11- deoxycortisol dan progesterone menjadi 11-deoxycortisone, yang merupakan prekursor untuk kortisol dan aldosteron. Defisiensi CYP21 menyebabkan gangguan pembentukan kortisol adrenal dan pada kebanyakan kasus juga mengganggu sintesa aldosteron. Gangguan pembentukan kortisol ini akan menyebabkan peningkatan sekresi adrenocorticotropic hormone (ACTH) oleh kelenjar hipofise yang pada akhirnya akan mengakibatkan pembesaran kelenjar adrenal, penumpukan dari precursor steroid dan produksi androgen adrenal yang berlebihan. Gangguan produksi kortisol dan aldosteron dapat menyebabkan kekurangan garam yang berat dan krisis adrenal, yang kebanyakan terjadi setelah minggu pertama kehidupan. Produksi berlebihan dari androgen adrenal menyebabkan terjadinya berbagai tingkatan virilisasi dari genitalia eksterna perempuan. ${ }^{10}$

\section{Manifestasi Klinis}

Gambaran utama bayi baru lahir dengan HAK tipe klasik atau berat adalah kerancuan kelamin (ambigus genitalia) pada bayi perempuan karena virilisasi yang berat, selain kondisi krisis kehilangan garam (salt wasting crisis). ${ }^{3}$ Sedangkan pada bayi laki-laki, gambaran awal yang muncul adalah krisis kehilangan garam dengan risiko kematian pada minggu-minggu awal kehidupan. ${ }^{11}$

Sekitar 75\% kasus HAK tipe klasik baik pada bayi laki-laki maupun perempuan akan mengalami defisiensi aldosterone dengan gejala kekurangan garam, gagal tumbuh dan berisiko mengalami krisis adrenal. Jika tidak didiagnosis secara tepat dan diobati segera, maka HAK akan menyebabkan kematian pada masa bayi akibat permasalahan-permasalahan tersebut. ${ }^{11}$
Bayi perempuan dengan HAK klasik baik tipe salt wasting maupun simple virilizing, biasanya mempunyai manifestasi klinis ambigus genitalia. Pada beberapa kasus, genitalia ambigu ini sudah dicurigai sejak dari USG prenatal. Genitalia eksterna bayi perempuan dengan HAK mempunyai variasi dari klitoromegali minimal hingga mendekati gambaran genitalia eksterna laki-laki namun tidak teraba testisnya. Yang tersering berupa klitoromegali dengan fusi labia mayora dan orifisium perineal tunggal. Pada bayi laki-laki, selain hiperpigmentasi, gambaran genitalia eksterna laki-laki normal. ${ }^{12}$

Bayi dengan HAK cenderung mengalami kesulitan minum dan gagal mencapai berat lahirnya dan jika tidak diatasi akan mengalami gagal tumbuh. Bayi dengan HAK tipe salt wasting biasanya akan mengalami muntah-muntah, hiponatremia, hiperkalemia dan hipotensi pada usia 10-14 hari dan jika tidak teratasi akan mengalami syok dan menyebabkan kematian. ${ }^{12,13}$

Pada masa anak, bisa terjadi pubarke prematur, yakni tumbuhnya rambut pubis lebih dini yakni sebelum usia 8 tahun pada anak perempuan dan sebelum usia 9 tahun pada anak laki-laki. Anak akan lebih tinggi dan mengalami percepatan pertumbuhan serta advanced boneage, yang pada akhirnya akan menyebabkan perawakan pendek di usia dewasa. Pada anak perempuan klitoromegali bisa berkembang, sedangkan pada anak laki-laki penis lebih besar namun besar testis normal. 12,14

Pada tipe yang lebih ringan, jika tidak terdiagnosis maka bayi laki-laki maupun perempuan akan mengalami pertumbuhan post natal yang cepat dan pubertas dini yang berakibat penutupan efisisis lebih cepat sehingga hasil akhirnya adalah perawakan pendek pada masa dewasa. Pada tipe ringan atau nonklasik yang muncul pada masa anak-anak akhir atau awal masa dewasa adalah kelebihan androgen yang merupakan penyebab penting dari maskulinisasi dan infertilitas pada wanita. ${ }^{4,15,16}$

\section{Diagnosis}

Identifikasi HAK lebih mudah pada anak perempuan, sedangkan pada anak laki-laki membutuhkan kecurigaan yang tinggi, khususnya pada HAK 21hydroxilase tipe salt wasting karena seringkali menimbulkan kematian yang tidak diketahui. Petunjuk penting adalah riwayat konsanguinitas dan kelainan yang sama pada saudaranya atau mempunyai saudara laki-laki yang meninggal saat usia bayi dengan muntahmuntah dan gagal tumbuh yang tidak bisa dijelaskan penyebabnya. ${ }^{2,3}$

Diagnosis defisiensi 21-hydroxilase berdasarkan peningkatan dari serum 17 hidroksi-progresteron (17OHP). Beberapa steroid yang juga meningkat adalah androstenedione, testosteron dan 21-deoksikortisol. Peningkatan Plasma Renin Activity (PRA) dan 
berkurangnya rasio aldosteron terhadap PRA menunjukkan suatu gangguan sintesis aldosteron, yang bisa digunakan untuk membedakan tipe salt wasting dengan simple virilizing. ${ }^{3}$

Beratnya kelainan hormonal tergantung dari derajat gangguan enzimatik yang tergantung dari genotipnya. Pemeriksaan genetik tidak bisa menunjukkan kondisi salt wasting. Kondisi salt wasting ditentukan dari kondisi klinisnya. ${ }^{3}$

\section{Terapi}

Pengelolaan komprehensif diperlukan dalam pengelolaan individu dengan HAK, termasuk di dalamnya adalah terapi medikamentosa, operatif dan konseling.

Terapi medikamentosa pada anak dengan HAK mempunyai tujuan utama(1) (2) menggantikan kortisol yang kurang dengan pemberian glukokortikoid, (3) mengurangi oversekresi dari ACTH sehingga mencegah sekresi androgen yang berlebihan dan mengganti aldosteron yang kurang dengan pemberian mineralokortikoid dan suplementasi garam. Tujuan lainnya adalah untuk membantu menjaga potensi reproduksi. Dosis pengobatan yang tepat akan membantu mencegah krisis adrenal, mengurangi virilisasi (maskulinisasi) sehingga dapat mencapai tumbuh kembang yang optimal. 8,10

Pengobatan seumur hidup dengan glukokortikoid dibutuhkan untuk semua tipe HAK. Pada tipe salt wasting, perlu ditambahkan juga mineralokortikoid dan $\mathrm{Na} \mathrm{Cl.}{ }^{8,17}$ Glukokortikoid pilihan pada masa bayi adalah hidrokortison dengan dosis rumatan 10-15 mg/luas permukaan tubuh/hari dibagi dalam 3 dosis. Hidrokortison mempunyai efek samping yang paling ringan dan paling aman dibandingkan preparat lain seperti deksametason, prednisolon ataupun prednison dalam hal mengganggu pertumbuhan tulang. Mineralokortikoid yang diberikan adalah fluodrokortison tablet dengan dosis $0.05-0.2 \mathrm{mg} /$ hari. Pada bayi HAK tipe salt wasting bisa ditambahkan $\mathrm{Na} \mathrm{Cl}$ $1-2 \mathrm{~g} /$ hari $^{3,10,13}$

\section{Pengobatan dalam kondisi kegawatan}

Anak dengan HAK bisa mengalami krisis addisonian yang harus segera diatasi. Orang tua harus diberikan edukasi tentang kondisi-kondisi yang memerlukan peningkatan dosis glukokortikoid dan idealnya anak diberikan tanda pengenal yang menunjukkan bahwa anak tersebut membutuhkan dosis tambahan atau injeksi untuk membantu pada saat krisis. ${ }^{17}$

\section{Skrining bayi baru lahir}

Skrining HAK pada bayi baru lahir amatlah tepat karena penyakit ini cukup sering ditemukan dan merupakan kelainan yang mengancam jiwa. Skrining dilakukan dengan pemeriksaan hormonal dalam darah yang cukup sederhana. Deteksi dini disertai terapi awal yang tepat bisa mencegah kekurangan garam yang berat, dehidrasi, dan krisis adrenal sehingga pada akhirnya akan mengurangi morbiditas dan mortalitas khususnya pada bayi laki-laki. Tujuan kedua dari skrining adalah untuk mencegah hiponatremia dan hiperkalemia. Selain mengancam jiwa, kekurangan garam ini mempunyai efek jangka panjang seperti gangguan belajar dan masalah perilaku. Manfaat lainnya adalah memperpendek masa penentuan jenis kelamin yang tepat. Bayi perempuan dengan HAK tipe klasik akan mengalami virilisasi mulai dari pembesaran klitoris yang ringan hingga maskulinisasi lengkap (ambigus genitalia). Perempuan dengan virilisasi nyata bisa mengalami kesalahan penentuan jenis kelamin menjadi laki-laki. ${ }^{16,18}$

Skrining massal neonatal untuk HAK akan mengidentifikasi baik bayi perempuan maupun bayi laki-laki sehingga akan mengurangi keparahan ambigus genitalia sekaligus mengurangi mortalitas akibat salt wasting. Oleh karena itu skrining HAK pada bayi baru lahir sangat direkomendasikan. ${ }^{19}$

\section{DAFTAR PUSTAKA}

1. Pinto G, Tardy V, Trivin C, et al. Follow-up of 68 children with congenital adrenal hyperplasia due to 21-hydroxylase deficiency: Relevance of genotype for management. J Clin Endocrinol Metab. 2003;88:2624-2633. doi:10.1210/ jc.2002-021433.

2. Trapp CM, Speiser PW, Oberfield SE. Congenital adrenal hyperplasia: an update in children. Curr Opin Endocrinol Diabetes Obes. 2011;18:166-170. doi:10.1097/ MED.0b013e328346938c.

3. Speiser PW, Azziz R, Baskin LS, et al. Congenital adrenal hyperplasia due to steroid 21-hydroxylase deficiency: an Endocrine Society clinical practice guideline. J Clin Endocrinol Metab. 2010;95:4133-4160.

4. Merke DP, Bornstein SR, Avila NA, Chrousos GP. Future directions in the study and management of congenital adrenal hyperplasia due to 21-hydroxylase deficiency. Ann Intern Med. 2002;136(4):320-334.

5. Turcu AF, Auchus RJ. Adrenal Steroidogenesis and Congenital Adrenal Hyperplasia. Endocrinol Metab Clin N Am. 2015;44:275-296.

6. Riepe FG, Sippell WG. Recent advances in diagnosis, treatment, and outcome of congenital adrenal hyperplasia due to 21hydroxylase deficiency. Rev Endocr Metab Disord. 2007;8:349363. doi:10.1007/s11154-007-9053-1.

7. Marumudi E, Khadgawat R, Surana V, Shabir I, Joseph A, Ammini AC. Diagnosis and management of classical congenital adrenal hyperplasia. Steroids. 2013;78(8):741-746. doi:10.1016/j.steroids.2013.04.007.

8. Speiser PW. Medical Treatment of Classic and Nonclassic Congenital Adrenal Hyperplasia. In: New M, Simpson J, eds. Advances in Experimental Medicine and Biology. Springer Science+Business Media; 2011:41-45. doi:10.1007/ 978-1-4419-8002-1.

9. Reisch N, Arlt W, Krone N. Health problems in congenital 
adrenal hyperplasia due to 21-hydroxylase deficiency. Horm Res Paediatr. 2011;76:73-85. doi:10.1159/000327794.

10. Claahsen-Van Der Grinten HL, Stikkelbroeck NMML, Otten BJ, Hermus a. RMM. Congenital adrenal hyperplasia Pharmacologic interventions from the prenatal phase to adulthood. Pharmacol Ther. 2011;132(1):1-14.

11. Barra CB, Silva IN, Pezzuti IL, Januario JN. Neonatal screening for congenital adrenal hyperplasia. Rev Assoc Med Bras. 2012;58:459-469. doi:10.1136/adc.58.10.803.

12. Witchel SF. Congenital Adrenal Hyperplasia. J Pediatr Adolesc Gynecol. 2017. doi:10.1016/j.jpag.2017.04.001.

13. Sharma R, Seth A. Congenital Adrenal Hyperplasia : Issues in Diagnosis and Treatment in Children. Indian J Pediatr. 2014;81:178-185.

14. Auchus RJ. The classic and nonclassic congenital adrenal hyperplasia. Endocr Pr. 2015;21:383-389.

15. Forest MG. Recent advances in the diagnosis and management of congenital adrenal hyperplasia due to 21-hydroxylase deficiency. Hum Reprod Updat. 2004;10(6):469-485. doi:10.1093/humupd/dmh047.
16. White PC. Neonatal screening for congenital adrenal hyperplasia. Nat Rev Endocrinol. 2009;5:490-498.

17. Hindmarsh PC. Management of the child with congenital adrenal hyperplasia. Best $\operatorname{Pr}$ Res Clin Endocrinol Metab. 2009;23(2):193-208. doi:10.1016/j.beem.2008.10.010.

18. Kamp HJ van der, Wit JM. Neonatal screening for congenital adrenal hyperplasia. Eur J Endocrinol. 2004;151:U71-U75. doi:10.1530/eje.0.151U071.

19. Clayton PE, Miller WL, Oberfield SE, et al. Consensus statement on 21-hydroxylase deficiency from the European Society for Paediatric Endocrinology and the Lawson Wilkins Pediatric Endocrine Society. J Clin Endocrinol Metab. 2002;87(9):4048-4053. doi:10.1159/000065490. 